\title{
胃腸蓮動に及济す椟熱の影響に関する研究
}

\author{
第 1 編

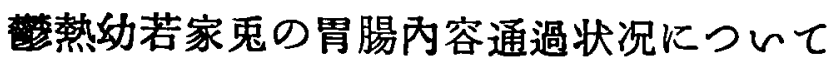 \\ 岡山大学医学部小児科敉室（主任：浜本数授） \\ 医学士安東弘道
}

〔昭和 29 年 10 月 27 日受稿]

\section{1 啨言}

我が国夏期に於ける重症消化不良症（乳児 口腸桨）は，欧米の栄養障碍症飞比し，罹患年 -4令, 無生時期, 症状等飞特異な点が多く，そ 4 の発生病理飞ついて，既飞各方面から多くの 研究が行われているが，末だ本態を充分解明 茟するまで至つていない，古来，本症は夏期 飞発生し且つ重症化の傾向を示すために，本 症発生の一因子として暑熱の影響が考えられ ているが，てれが如何にして作用するかを本 質的に究明したものはない，浜本教授はこの 点飞盖み，梅雨期並びにこれに先だつ数ケ月 間に乳先を厚着させる習慣が本邦特有の高温 高湿気候と相俟つて，長期間乳児を警熱状態 飞陥れ，これが乳児の間葉組織の機能を破綻 せしめ, 感染防繁能力の失坆を来し, 引いて 大腸菌の上㫒乃至增殖, 感染の合併を招来し, これらの悪循環を形成することとより，ての 夏期の下㢉症を容易飞重症消化不良症に移行 せしめるのではないかと考えた”。この点に 関して，既《教室の藤原 ${ }^{2}$ ，烟野 ${ }^{31}$ ，猪木 ${ }^{2}$, 重岡5) 等は, 重症消化不良症患児並びに長期 間整熱環境下に飼育した幼若動物について, 種々の角度から研究を行い，間葉機能の低下 を立証している所である.

一方, Moro' ${ }^{6}$ 及び Bessau ${ }^{71}$ が相次いで消 化不良症患児の胃及び十二指腸に多数の大腸 菌を発見して以来，我が国に於ても，鎮目 ${ }^{8)}$, 矢野9)，小山(10)，谷口 ${ }^{11)}$ 等は本症患䅐の腸管 上部に大腸菌の增殖を一様に認めており，こ れが本症と密接な関係にあることは疑う余地
がない。このよ5な胃及び小腸上部に於ける 大腸菌の增殖については，一般に，胃及び腸 管の機能が変化し小腸上部に食䬣が停滞し， 従つてこ〉に細菌増殖の素地が形成される結 果生ずる三次的現象と考えられている。（太 $\boxplus^{12)}$ )

私共が重症消化不良症の発生病理上重要な 位置を占めると考えて来た長期酒る慢性整 熱と腸内菌叢異変との関聯については, 先に, 教室の重岡 ${ }^{31}$ 等白鼠の胃及び腸管各部に 於ける大腸菌出現率の增加並び飞胃内容 $\mathrm{pH}$ の上昇を認め，小田 ${ }^{14)}$ は椟熱白鼠の腸管各部 飞於ける大腸菌数の增加を証明している。そ れに引き続き，私は，この腸内菌叢異変の先 駆をなすと考えられる胃腸機能就中胃腸運動

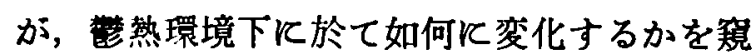
ろため，先ず本編では，熱熱幼若家鬼につい $\tau$, 胃腸内容の排出通過状況を造影食䬣を与 えて,レントゲン学的に検討した.

\section{2 実験材料並ひにに方法}

\section{(1) 実験材料}

体重 320乃至 $430 \mathrm{~g}$ （平均 390g） の白色健康 家鬼を潠び，これを新産児哺育用クべウスに 入れ，湿球温度 $23^{\circ} \mathrm{C} 2$ 日， $25^{\circ} \mathrm{C} 2$ 日， $26^{\circ} \mathrm{C}$ 3 日, $27^{\circ} \mathrm{C} 6$ 日, $\left\{28^{\circ} \mathrm{C} 10\right.$ 日, $29^{\circ} \mathrm{C} 10$ 日, $30^{\circ} \mathrm{C}$ 14 日の如く潮次温度を上昇せしめつ〉，計47 日，湿度 80 乃至 $90 \%$ の高温高湿環境下に飼

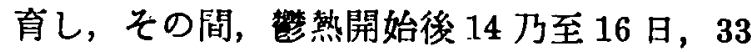
乃至 35 日，45 乃至 47 日の 3 回飞互つて次の 笑験を行つた。, 又, 別飞平均鼬球温度 $14^{\circ} \mathrm{C}$, 平均湿度62\%の平温噮境下に飼育したものK 
つき，同様の実験を行つて対照に供した。な お，飼料は豆腐粕及び緑草を用い，両群とも 全く同様に与えた。

\section{（2）実験方法}

前記家兔を24時間絶食後，特飞調製した造 影慨即ち硫酸バウム (石津) $30 \mathrm{~g}$ ，小麦粉 $4 \mathrm{~g}$ ，水 $100 \mathrm{cc}$ を混和，弱火著沸泥状と為し更 に穊で滤過し， 37 乃至 $38^{\circ} \mathrm{C}$ 飞温めたものを 每瓦体重 40ccソンテデより直接胃内に注入 ᄂ, 注入後 3 分, 10 分, 30 分， 1 時間，以 後30分毎に 7 時間まで， 7 時間以後 1 時間毎 そ16時間まで，16時間以後 8 時間毎に，何れ る腹背位によるレントゲン線透視を行い，数 例は透視と平行して撮影を実施した，透視並 びに撮影飞際しては，家鬼を着脱容易な自家 考案の固定装置により每回同一体位湢定し た。な括，造影食注入 24 時間以後は普通飼料 を与えた。

検查事項及び方法：上述のように固定した 家鬼を管球と一定距離に保つた營光板下に密 着せしぬ，胃陰影の逶視描写図を描き，注入 3 分後の面積を 100 とし，以後時間的経過飞 従い同様測定したものを百分率で算出し，注 入後 7 時間まで観繁し，胃陰影面積の時間的 推移を以て，胃内容排出機能を推測した。更 K，幽門部通過開始，小腸陰影消猋，盲腸陰 影出現，結腸飞於ける殞塊形成亚び飞全腸管 より陰影消失の各時間を求め，腸管内容通過 状況を検討した。

\section{3 実臨 成績}

\section{（1）胃陰影残留面積の時間的推移}

先ず，透視図の信頼性を確めるために，透 視と平行して撮影した 28 葉のレントゲン写真 の胃陰影面積を透視図同様百分率により算出 し，透視図のそれと比輘したところ，これら

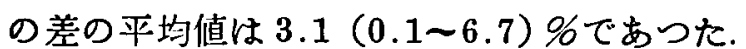
この值は胃の運形飞よつて透視時と撮影時と で胃の形状に変化を来すために生じた差異も 含まれ，透視図描写の誤差のみによるるので はないと考えられ，私の実駼方法によつて充 分比較検討し得るすのであることを確認し
た.

実験成績は第 1 表に示す通りであるが，先 ず，成長と共にとの胃内容排出状況に差を来 すか否かを見るため，対照群の中，No. 12, 14，15，16の 4 頭は何れる 24 乃至 30日の間 隔をへだて〉，同一獣とつき前後 2 回の検査 を行つて見た，その結果，第 1 回年少時の供 食 3.5 時間後に於ける胃陰影残留面積の平均 值は供食 3 分後の $24.1 \%$ ，第 2 回成長時のそ れは 18.3 \%であり，又， 7 時間後の胃陰影 残留面積平均値は同様 3 分後の夫々 3.8 及び 8.6 \%で，共に殆ど差を認め得なかつた。 こ れにより，この胃内容排出機能は年令飞関係 なく，又，仮令成長に伴 5 胃内容積の增加が

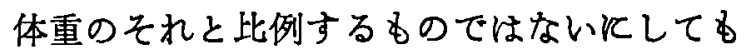
毎仟体重 40cc の注入量すほら゙適量であつた と考える。

次に，対照群及び熱各群飞於ける胃内容 排出状況を供食 7 洔間後の胃陰影残留面積に ついて見ると，対照群 (12 例) では平均 6.4 土3.4\%であうた。（第1図，第 2 図）熱 群㐸於ては，比輍的短期間の 14 乃至 16 日群 （6 例，以下15 日群と略記）では，No. 1，2， $5 の 3$ 例は遅延し， これらに於ては上記残留 面積は 28.1 乃至 $39.6 \%$ \%あり，他の 3 例は 対照と同様であつた，33 乃至 35 日群（6 例， 以下34日群と略記）では，活う各例飞平均し てや〉排出遅分が認められ，平均 $20.9 \pm 6.0$ \%であつた．又，45 乃至 47 日群（6 例，以 下46日群と略記）飞於ては，殆ど全例飞著明 な排出遅延を認め，平均 $32.0 \pm 9.7$ \%であつ た。（第 3 図，第 4 図）又，一方から見ると， 各群平均值について，約 $50 \%$ 残留の時間は， 対照群 30 分, 15 日群及び 34 日群 1 時間, 46 日群 2 時間であり，同様飞約 $20 \%$ 残留即ち大 部分を排出する時間は，対照群 3.5 乃至 4 時 間，15日群及び34日群 7 時間であり，46日群 では 7 時間後飞於てあなお32\%の残留を認め ている.

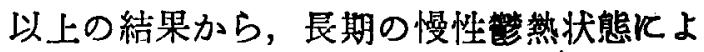
つて胃内容排出機能は著明飞低下することが 明かである。 


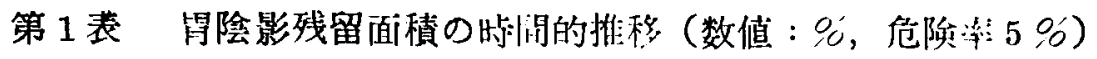

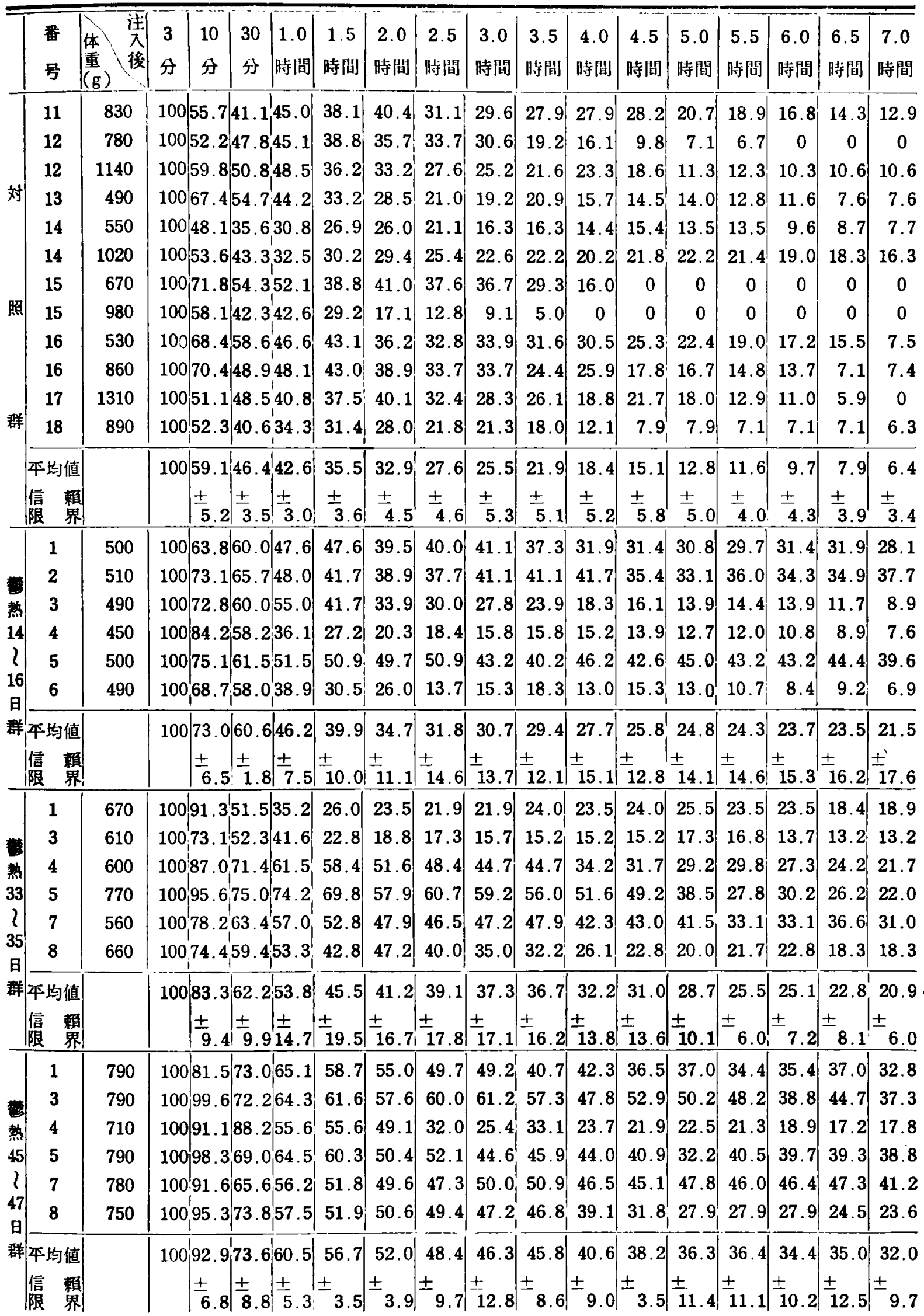

（2）幽門部亚び腸管各部の通過時間 門門部及び腸管各部の通過時間も第 2 表対
照群 No. 12, 14，15，16 についての 2 回の 実騒で見る如く，年令による差異は認め難い。 
第 2 表 腸管各部通過時間

\begin{tabular}{|c|c|c|c|c|c|c|c|}
\hline & 昂 & $\begin{array}{c}\text { 重 } \\
(\mathrm{g})\end{array}$ & 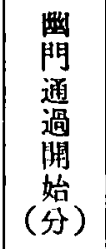 & 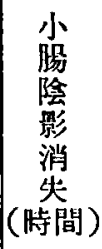 & 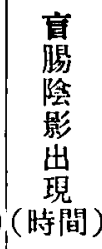 & 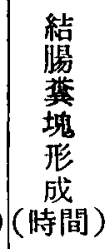 & $\begin{array}{c}\text { 全 } \\
\text { 陰 } \\
\text { 影 } \\
\text { 消 } \\
\text { 失 } \\
\text { (時間) }\end{array}$ \\
\hline & 11 & 830 & 3 & 6.5 & 1.5 & 5.5 & \multirow{5}{*}{64} \\
\hline & 12 & 780 & 10 & 6.0 & 1.5 & 5.0 & \\
\hline & 12 & 1140 & 3 & 7.0 & 1.5 & 6.0 & \\
\hline & 13 & 490 & 3 & 4.5 & 1.0 & 4.5 & \\
\hline & 14 & 550 & 3 & 7.0 & 1.5 & 6.0 & \\
\hline & 14 & 1020 & 3 & 6.5 & 1.5 & 6.5 & 72 \\
\hline \multirow{4}{*}{ 照 } & 15 & 670 & 3 & 6.0 & 1.5 & 4.5 & \\
\hline & 15 & 980 & 3 & 6.5 & 2.0 & 4.5 & 48 \\
\hline & 16 & 530 & 10 & 7.0 & 1.0 & 5.0 & \\
\hline & 16 & 860 & 10 & 7.0 & 2.0 & 4.0 & 64 \\
\hline & 17 & 1310 & 3 & 6.5 & 1.0 & 4.5 & 56 \\
\hline & 18 & 890 & 10 & 5.5 & 2.0 & 5.0 & 64 \\
\hline & 平均值 & & 5.3 & 6.3 & 1.5 & 5.1 & 61 \\
\hline & $\begin{array}{l}\text { 賴 } \\
\text { 界 }\end{array}$ & & \pm 2.2 & \pm 0.4 & \pm 0.4 & \pm 0.4 & \pm 11.0 \\
\hline \multirow{8}{*}{$\begin{array}{c}\text { 繁 } \\
14 \\
\text { 16 } \\
\text { 日 }\end{array}$} & 1 & 500 & 10 & 7.0 & 2.0 & 7.0 & \\
\hline & 2 & 510 & 10 & 6.5 & 1.5 & 8.0 & \\
\hline & 3 & 490 & 3 & 8.0 & 1.5 & 5.5 & \\
\hline & 4 & 450 & 3 & 6.5 & 2.0 & 6.5 & \\
\hline & 5 & 500 & 3 & 6.0 & 2.0 & 9.0 & \\
\hline & 6 & 490 & 3 & 10.0 & 2.5 & 10.0 & \\
\hline & F均値 & & 5.3 & 7.3 & 1.9 & 7.7 & \\
\hline & 賴 & & \pm 3.9 & \pm 1.7 & \pm 0.4 & \pm 1.7 & \\
\hline \multirow{7}{*}{$\begin{array}{c}3 \\
33 \\
\text { 熱 } \\
35 \\
\text { 日 }\end{array}$} & 1 & 670 & 3 & 7.0 & 2.0 & 8.0 & \\
\hline & 3 & 610 & 3 & 9.0 & 1.5 & 6.5 & \\
\hline & 4 & 600 & 3 & 10.0 & 2.5 & 10.0 & \\
\hline & 5 & 770 & 60 & 12.0 & 3.0 & 11.0 & \\
\hline & 7 & 560 & 3 & 12.0 & 2.5 & 11.0 & \\
\hline & 8 & 660 & 3 & 10.0 & 2.0 & 9.0 & \\
\hline & \begin{tabular}{|l} 
平均值 \\
$\mid$ 信 \\
乘
\end{tabular} & & $\begin{array}{r}12.5 \\
+24.5 \\
\end{array}$ & \pm 2.0 & $\begin{array}{r}2.3 \\
\pm 0.3 \\
\end{array}$ & $\begin{array}{r}9.3 \\
\pm 1.9 \\
\end{array}$ & \\
\hline \multirow[b]{6}{*}{ 日 } & 1 & 790 & 10 & 13.0 & 2.5 & 10.0 & 96 \\
\hline & 3 & 790 & 90 & 13.0 & 4.0 & 8.0 & 104 \\
\hline & 4 & 710 & 10 & 10.0 & 2.0 & 7.0 & 96 \\
\hline & 5 & 790 & 60 & 14.0 & 3.5 & 7.0 & 104 \\
\hline & 7 & 780 & 10 & 14.0 & 2.0 & 15.0 & 96 \\
\hline & 8 & 750 & 30 & 10.0 & 2.5 & 9.0 & 96 \\
\hline \multirow{2}{*}{\multicolumn{3}{|c|}{ 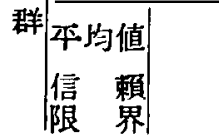 }} & 35.0 & 12. & 2.7 & 9.3 & 99 \\
\hline & & & \pm 35 & & & \pm 2.8 & \pm 6. \\
\hline
\end{tabular}

次に第 2 表の通り，幽門部通造開始時間は，

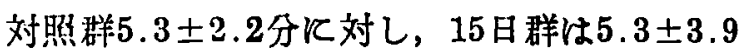
分で全く差は見られず，34日群 No. 5 の1例 飞60分，46日群 No. 3，5，8の3 例飞!30万至 90 分の荤延を認めた。次飞，小腸陰影消失時 間は対照群 $6.3 \pm 0.4$ 時間であり，15 日群は $7.3 \pm 1.7$ 時間で対照群とほ心゙同様の結果を示

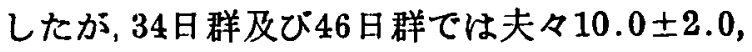
$12.3 \pm 2.0$ 時間で明かに痋延していた。盲腸 陰影出現時間は対照群1.5土0.4時間，15日群 $1.9 \pm 0.4$ 時間，34 日群 $2.3 \pm 0.3$ 時間，46日

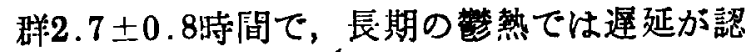
められた．結腸江於ける䙪塊形成時間は対照 群 5.1 0 0.4 時间化比し， 15 日群，34 日群， 46 日群の順に夫々 $7.7 \pm 1.7,9.3 \pm 1.9,9.3$ \pm 2.8 時間の如く延長し, 長期の熱は岉論, 14万至16日のよ5な比較的短期の熱すある 程度腸管の輸送機能を低下せしめることを認 めた，最後に，全陰影が腸管より消失する時 間は，対照群 6 例と46日群飞ついてのみ検查 したが，その結果は $61 \pm 11.0$ 及び $99 \pm 6.0$ 時 間で長期の熱では著明な延長を示した。

以上の上 $5 k ＼mathrm{~ ， 腸 管 各 部 の 内 容 通 過 時 間 ~}$ 胃内容排出状況々同様，栕熱日数が長期仾 る程明か长唇する傾向を認めた。

\section{4 考按}

正常家鬼のレントゲン検查による胃内容排 出状況飞関しては，浦野15)，本城 ${ }^{16)}$; 松枝 ${ }^{171}$ 等の下記の如き記載があるが，何れも成熟家 鬼を使用して括り，私の実験のよ5飞幼若家 鬼を用いて，胃陰影面積の時間的推移により 胃内容排出機能を追求した研究はこれを見な い.その中最も詳細な松枝の報告によると， 成熟家鬼飞 60cc の造影食を注入した場合, 供食直後， 30 分， $1.5 ， 3 ４ .5 ， 6$ 時間飞こ れを検した所，造影食は胃内注入後30分以内 飞些門部を通過し，4.5 乃至 6 時間で大部分 が排出されるが，その後る長時間少量の残留 食を止める例が多く，その後な拓永く完全に は内容が空虚となり難いと述へ，他の研究者 るほょ同様の見解を持している，更飞，幽門 
部通過とついて，氏は供食直後即ち 2 乃至 3 分以内に既に幽門部通過を開始した例を認め ず, 本城 ${ }^{16)}$ は供食後胃内容の幽門部排出開始 は平均59分であつたと記載している。私の実 検で供食後 3 分，10分，30分，1時間，以 後30分毎にこれを検したのであるが，対照健 康家象の胃内容排出状況は概ねこれらの成績 に一致してはいるが，たよ私の場合，多くは 殆ど供食直後に，荤くも10分以内に然門部通 過を開始している点はや〉異る。恐らくこれ は, 私の場合レ線検查の回数が多く, 且又, 使用した造影食が氏等のそれに比しょり流涠 状で而も注入量が比較的大であつた為と考え られる。

次に，腸管各部の通過時間飞関して，前記 松枝は私と同様の観察を行い，ほ心相似た成 績を発表しているが，小腸陰影消失時間につ いては些か趣を異にしている. 即ち, 私の対 照例 4.5 乃至 7.0 (平均 6.3）時間飞対して, 氏は 3 乃至 4.5，稀飞 6 時間であつたという。 これも造影食の量が或は影響したのかも知れ ない.

さて, 高温乃至高温高湿環境が胃運㡖に及 ほす影響に関しては，既に多数の業績が見受 けられる. 即ち, W. Borchardt ${ }^{18)}$ は人工気候 室による高温高湿環境下に於て，十二指腸瘦 犬につき，胃内容排出機能が著しく減弱する ことを確認し, Müller \& Hölscher ${ }^{19)}$ む人工 気候室内でパロン法による人体実験の結果,

胃運動は加温直後は元進するが，これを持続 すると却つて減弱し，運動曲線の振幅は小と なると述へ，稲生及び河野2n'は健康人並びに 消化器疾患々者につき, 気温 20 乃至 $24^{\circ} \mathrm{C}$, 湿度 70 乃至 $90 \%$ の室内之, 気温 $35^{\circ} \mathrm{C}$, 湿度 40.30高温低湿人工気候室と飞於て, 胃排出 機能をレ線検査並びと Coffein 法による採取 胃液の青色消失時间飞よつて比較し，か」る 高温低湿の場合は胃排出機能は著しく低下す るととを認めた，又，福島 ${ }^{21)}$ 等は成熟家兔を 種々の温度と湿度とを組合せた人工気候室内 K3 時間放置し，ハロン法により胃運動を検 した結果, $30^{\circ} \mathrm{C}$ 以上の高温は胃運動を減弱

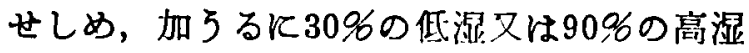
に於ては，胃運楀は更に著しく減弱与ること を確めている. 又，気温の上早が腸運㮩に及 ぼす影響に関して，福島及び均北"21は腹密家 压の盲腸運㡖が高温高湿環境下で著しく抑制 されると記㦲している.

しかしながら、これらの業績はすべて数時 間前後の短期間の趁就による胃腸運鲴の变化 を検したにすぎず，私の如く数十日に及ぶ長

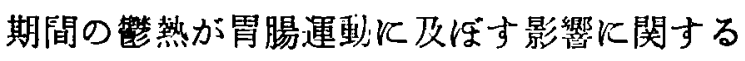
研究殊にレントゲン検查による業績は未だ見 あたらない。たら，福島及び管野"1)成熟南 京鼠を温度 $32^{\circ} \mathrm{C}$ ，湿度 $90 \%$ ，56 \%及び $30 \%$ の人工気候室内反 30 日間飼養し，その間経過 を追つて開腹し, 剔出胃筋片の自発的收縮運 動を Magnus 氏法により検した結果, 高温環 境飞於ては，湿度が上昇若しくは低下する場 合，共飞胃筋の收縮门は初期 1 万至 2 日間一 時的に増強するが，その後は日数の経過する に従つて追々と減弱すると述へている.

上述の文献に見る通り, 櫊熱環境が胃腸運 動の減退をるたらすということは研究者多数 の一致して説く所であるが，私のように幼若 家鬼を長期間㯱熱環境下に飼育し，レ線検查 によつて胃腸内容の排出亚びに通過状況を見 ても，同様胃内容排出遅延並びに腸管各部通 過時間の延長を認めた。これらの事奏は警熱 が原因となつて二次的に胃腸機能の低下を来 したるのと考えてよいようである。

又，胃機能の他の一面としての胃液分泌に 高温高湿環境が及ほす影響は, 当面の研究 目標でないため，略述するに止まるが，

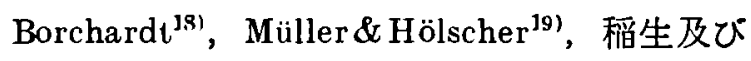
河野 ${ }^{201}$ ，中村 ${ }^{22)}$ ，吉田 ${ }^{23)}$ 等は，人体或は動物 実験によつて, 分泌減弱, 総酸度並びに遊離 塩酸隄低下を認め，就中，吉田は夏期及び人 工気候室の高温高湿環境下に於ける乳児の胃 液分泌機能低下を認めている，又，教室の重 岡 ${ }^{13 i}$ は私と同様の警熱形式による幼若白鼠の 胃内容 $\mathrm{pH}$ の上昇を立証している。

一方，既飞緒言に言及したよろに，1905年 $\mathrm{Moro}^{6}$ ) は食飽性中毒症で死亡した患児の小腸 
上部から，続いて1919年 Bessau \& Bossert ${ }^{71}$ は十二指腸ソンデにより，直接中毒症患児の 胃及び十二指腸から多数の大腸菌を検出した が，それ以来，我が国於ても，鎬目 ${ }^{8)}$ ，大 久保 ${ }^{24)}$, 矢野9), 小山 ${ }^{(11)}$, 徳永 ${ }^{2(1)}$, 谷口 ${ }^{11)}$, 岡田 ${ }^{26)}$ 等によつて，重症消化不良症患㫛の胃 並びに小腸上部に大腸菌の增殖が認められた。 Moro ${ }^{(i)}$ はこの腸管上部の大腸阙はすへて廻 腸及び大腸から上昇したものであるという Coliascensionstheorie を樹立し, Bessau ${ }^{7)}$ もこ れに同調した. 更に, Moro は如何なる因子 がこの大腸菌上昇の本質的原因であるかを， 脂肪酸, 下剂, 糖, 高熱等を与えて検査し, このうち糖と高熱とが最も著しい小腸感染を 招来することを述へてている. 又，小山沙)は大 腸菌の小腸上部への上昇繁殖は下莉発生の直 接原因ではなく，むしろ二次的意義を有する あのであることを立証した。近年, Braun 27

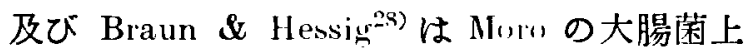
昇説を否定し，消化不良症䅐の胃及び十二指 腸に於ける大腸菌は下部腸管から上昇したも のではなく，その場で二次的に增㪶したもの であると説いた．このように，その原因につ いては見解が区々であるが，何れにせよ，今 日，重症消化不良症と胃或は小腸上部に於け る大腸菌を主とする細菌の增殖とが密接な䦎 係にあることは否定できない事実といわねば ならぬ.

かような胃並びと小腸上部の細菌の増殖 は，一般には，Bessau住等がいううに Chymusstagnation によるものと解されてい る. 即ち，胃及び腸管の正常な機能が阻害さ れ，蠕動障碍或は分泌機能の低下を米し，胃 並びに小腸上部に食餌が停濡し，従つてこ」 に細菌増殖の素地を形成するためであるとさ れている，それでは，臨彇上重症消化不良症 或は中毒症の患児飞於て，胃腸機能の低下即 ち胃液分泌障碍，乳糜の停滞が見られるかと い5 していると述へ，小山国，徳永 ${ }^{25)}$ 等はや」酸 性に傾く々記载しているが，胃液の遊離塩酸 並びそ総酸度の著明な隇少は諸家 (211)263302の
何れも認めている所である，又，Dittrich'1! はレントダン学的に造影剂を使用して中毒症 患児の胃腸運動並びに内容通過状況を詳細飞 检討し，胃及び小腸運動機能の減退，甚だし いものでは腸麻疸を認め, 内容通過は著しく 遅延していることを記載し， 原 ${ }^{321}$ ，小田切 ${ }^{33}$ 等もレ線透視により，ガス集積の著明なとと

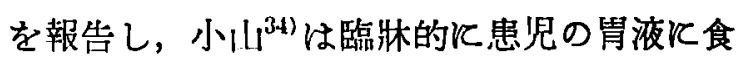
後長時間比互つて食慨残渣を混している事実 から，胃の排出が著明に遅延していることを 認めている. 以上のように，多くの研究者 は，重症消化不良症或は中毒症の際に胃腸内 容の停算を認めて括り，本症と胃腸内容の停 満並び胃及び小腸上部に於ける大腸菌の増 殖との三者の間には密接不離な関係があると いつても大過ないであろう。

䧽つて，我々の教室に於ては，長期間の慢

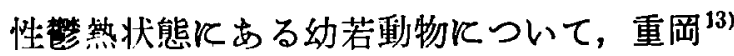
は胃及び腸管各部特に空腸上部並びに結腸に 於ける大腸菌出現率の增加, 胃内容 $\mathrm{pH}$ の上 昇を認め，小田 ${ }^{141}$ は胃並びに腸管各部の大腸 萢数增加を証明した．又，栗原 ${ }^{35)}$ は幼若家鬼 飞つき, Streptomycin 耐性大腸菌を十二指腸 そ注入し， 3 時間後の菌数が倈熱群に於ては 対照群より大であることを認めて扣り，これ が腸粘膜殺菌力の低下並びに腸管運動機能隇 退の為であろうとしている，更に又，前記小 田はTrypanblau 飞よる網状織内被細脃系填 塞白鼠の胃及び腸内大腸菌の著明な增加を立 証して，私共が従来唱えている罍熱と間葉機 能の低下並びそ大腸菌の異処的増殖との三者 の関係に一つの示唆を与えたのである. 私も 亦, この点を解明するためと本編の実験を行

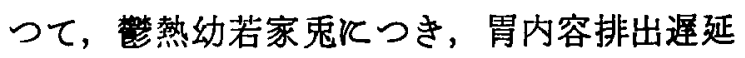
並びに腸管各部の内容通過時間の延長を確認 したのであるが，如上の文献的考察及びこれ らの実験成績から，私注，熱による胃腸機 能の減退が間葉機能の低下 ${ }^{233)}$ と相俟つて 重症消化不良症の発生に重要な役割を演ずる そ考えるすのである。 


\section{5 䋓括並びに結論}

惯性敏熱によつて胃腸運野の5ける影響を 知らんとして，次の実験を行つた，幼若家鬼 を湿球温度 23 乃至 $30^{\circ} \mathrm{C}$, 湿度 80 乃至 9096 の

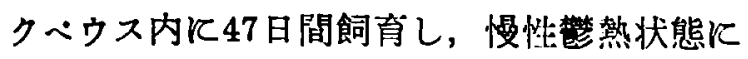
宿れ，その間 14 乃至 16 日，33 乃至 35 日及 び 45 乃至 47 日の 3 回に互り, 造影食を胃内 飞注入し, $V$ 線検查飞よつて, 胃陰影面積の 時間的推移並びそ腸管各部の内容通過時間を 检討し，次の結果を得た。

(1) 胃陰影面積は供食後 7 時間伦於て，対 照群（12例平均）では供食 3 分後即ち殆ど供 食直後陰影の $6.4 \% ， 14$ 万至16日群（6 例平 均）で $21.5 \% ， 33$ 乃至 35 日群（6 例平均） で20.9\%，45 乃至 47 日群（6 例平均）では $32.0 \%$ が夫々残留した。

（2）幽門部通過以対照群及び14乃至16日群 には差を認めず，共飞平均 5.3 分，33乃至 35 日群 12.5 分, 45乃至47日群 35.0 分であつた。

（3）小腸陰影消失時間は, 対照群平均 6.3

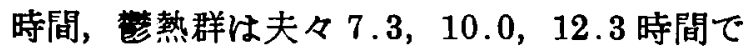
あつた。

（4）盲腸陰影出現時間は，対照群 1.5 時間, 䇾熱群は夫々 $1.9,2.3,2.7$ 時間であつた。

（5）結腸飞於ける翼塊形成時間は，対照群
5.1 時間，警熱群は夫々 $7.7,9.3,9.3$ 時間 であつた。

（6）腸管から全陰影が消失する時間は，対 照群 61 時間，45 乃至 47 日群 99 時關であつ た.

以上のよ て, 胃内容停㴋並び腸管内容通過遇延を認 めた．今日，重症消化不良症患斻飞於て，乳 糜の停滞が胃及び小腸上部に大腸菌の增殖を 惹起せしめる素地的因子を為すと一般に考兄 られているが，以上の実験成績と併世考える と, 従来私共が唱兄て来た重症消化不良症は 熱熱によつてか」る大腸菌の異処的增殖をる たらし易い渠備状態即ち間葉機能の破綻に上 る Dysergie の結果発生するという考を, 単 飞腸内菌萨の変化或は腸粘膜殺菌力の低下の みならず，胃腸内容停漁の面からも立証し得 たと考劣るすのである.

䊏りにのぞみ本研究を命ぜられ䊀始御愁篤な御指

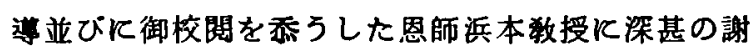
意を表します。

本研究は文部省科学研究費飞負了所大であります。 な怙本稿の要旨は昭和28年 4 月日本小児科学会第 56 回総会並び同年 6 月岡山医学会第63回総会江発 表した.

(文献 得 进)

\section{附 図 說 明}

第 1 四 No. 13 （対照）体重 490g，造影食 $20 \mathrm{cc}$ 注入，供食 5 分後撮影.

胃内容既飞罒門部を通過，小腸陰影出現す。

第 2 园同上家兔，供食 6 時間後撮影.

胃内容大部分排出され，小腸陰影消失，盲腸陰影充满し，中腹部飞䔬塊を認を.

第 3 园 No. 1 (睝熱45日）体重 790g，造影食 $32 \mathrm{cc}$ 注入，供食 5 分後撮影.

胃内容末だ呦門部を通過せず。

第 4 因同上家鬼，供食 6 時間後撮影.

胃内容な拓相当量残留，小腸陰影消失せず，亩晹陰影極めてうすく，算塊を認めず. 
Department of Pediatrics, Okayama University Medical Schoal.

(Director Prof. Dr. E. Hamamoto)

Studies on Gastro-intestinal Movement in High Temperture and Humidity.

Chapter I. The Passage Time of Food through Stomach and Intestines of the Young Rabbits under Hot and Humid Environment.

By

Hiromichi Ando.

Young rabbits were reared in the environment with the wet temperature ranging from 23 to $30^{\circ} \mathrm{C}$ and with the humidity of 80 to 90 per cent for 47 days, and then the passage time of food through their stomach and intestines was examined by roentgenologic method.

The following results were obtained

1. Under hot and humid environment the prolongation of the pyloric passage was found in 3 of 6 cases.

2. Under these conditions the passage time of food through the stomach and intestines was remarkably prolonged as compared with of control animals. 


\section{安束論文附図}
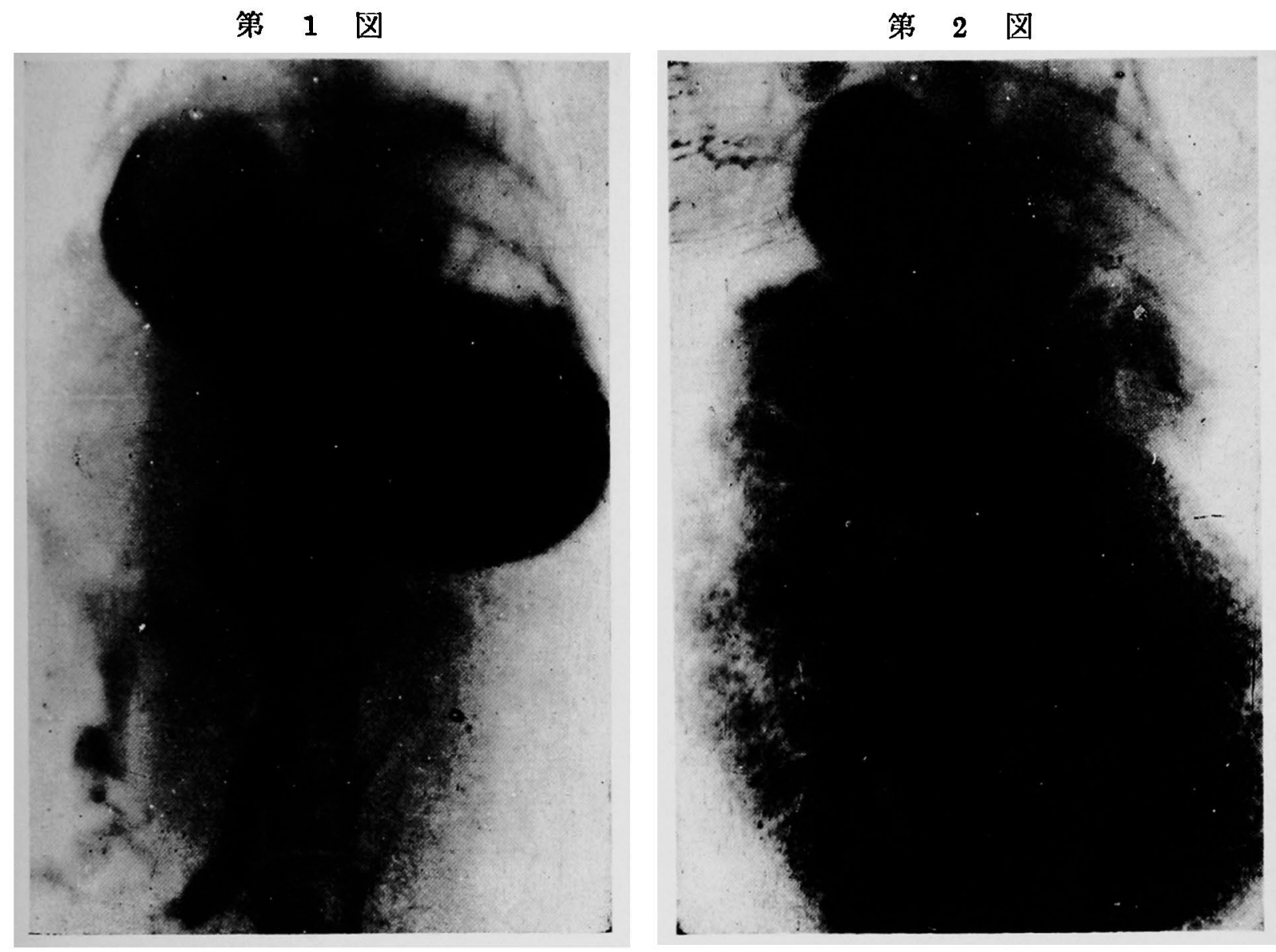

第 3 図

第 4 図
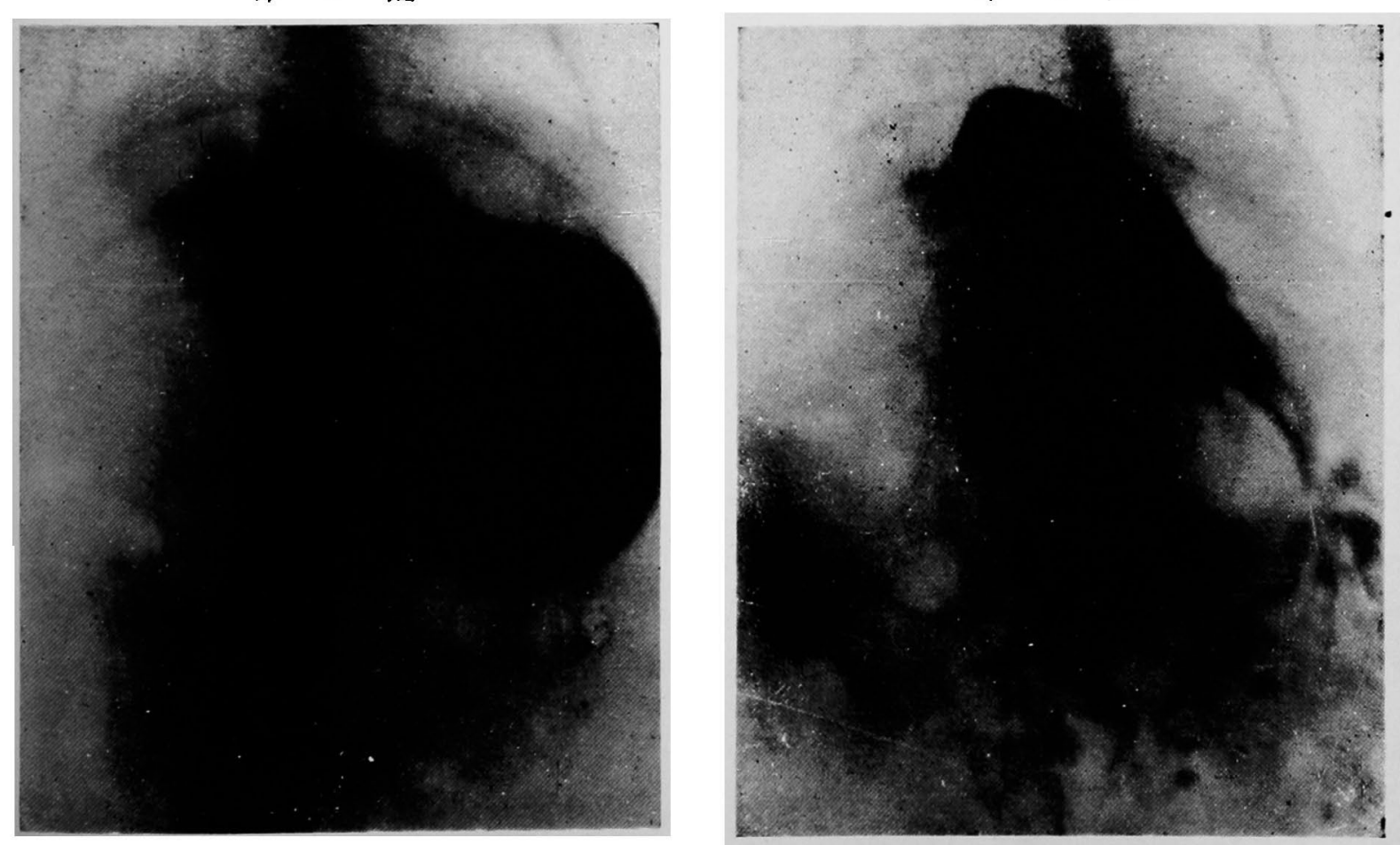